\title{
Effects of Career Exploration Module on Career Planning, Career Self-Efficacy and Career Maturity among Community College Students
}

\author{
Jasmi Bin Abu Talib \\ Universiti Malaysia Terengganu; jasmi@umt.edu.my \\ Zakaria Mohamad \\ Universiti Malaysia Terengganu; zek@umt.edu.my \\ Norwaliza Abdul Wahab
}

Universiti Pendidikan Sultan Idris; norwaliza@fppm.upsi.edu.my

\section{Doi:10.5901/mjss.2015.v6n6s1p464}

\section{Abstract}

This study aims to look at the impact of the Career Exploration Module on the ability of career planning, career self-efficacy and career maturity among community college students. A quasi-experimental design was used to evaluate using non-equivalent pre-test and post-test control group. The sample comprised 122 semester four students from two community colleges in the state of Malacca. Data were collected using three sets of instruments; i) Career Planning Competencies Instruments to measure the ability of career planning, ii) Career Maturity Inventory-Revised (CM-R) to measure attitudes and skills in career planning and iii) Career Decision Making Self Efficacy Scale (CDMSE-SF) to measure the level of students' career self-efficacy. The reliability of the instruments was analyzed using Cronbach Alpha and the value for all three instruments exceeded .70. Data were analyzed using descriptive and inferential statistics. Descriptive analysis uses mean, frequency and percentage to see the difference between groups while inferential analysis uses MANOVA to see the difference between the groups after the experiment. The results showed that there was a significant difference between the control group and the experimental group for the variables of the abilities of career planning, career self-efficacy and career maturity after the experiment. The results of the experiment have shown that the ability of career planning, career self-efficacy and career maturity can be improved if students follow a systematic career program. The usage of Careers Exploration Module has proven to build community college students in improving their career skills.

Keywords: career planning abilities, career self-efficacy, career maturity, community colleges

\section{Introduction}

The awareness of planning and choosing careers among students in Malaysia is still low either in secondary schools or in institutions of higher learning. Inventory issues from mental and social aspects in career planning is one of the problems encountered causing some of the students to fail in interviews. There are also students who are unable to make any decision in career planning (Hanirunnaja 2008). Weaknesses in terms of general knowledge and career information have caused the students in this country to be less sensitive, less informative and they are not up to date with career development. In addition, they do not seem to put much effort in getting information about job opportunities. (Abdul Rahim Abd Rashid, 2006; Amla, 2002; Abd Halit, 2007; Hanirunnaja, 2008; Sidek Noah, 2002; Syed, 2010; Zulkefli, 2000).

This problem also occurs among community college students. Several studies have been conducted on community college students which have given us preliminary information regarding the issues found among them (Mizan, 2005). Studies on Mobility Services Community College Student Personnel which were conducted nationwide, discovered that the aspects of career that have become a major problem for students are: i) students have little knowledge in terms of future planning, ii) students are vague in choosing careers, iii) need help in securing a job, iv) do not know how to find a job and, v) the fear of unemployment.

The feedback obtained from Kajian Pengesanan Graduan Kolej Komuniti from 2008 to 2010 also shows that the career development skills are some of the extra skills needed by the students. In addition, support programs such as English language skills, ICT skills, entrepreneurial skills and interpersonal skills are also required. In addition, students' 
perceptions toward career guidance especially assistance in job applications, assistance in preparing for interviews, information on jobs and careers are also low. The study found that they were not satisfied with the career guidance services provided in community colleges and they require more guidance in terms of career informations (Kajian Pengesanan Graduan Kolej Komuniti Report, 2008-2010).

The response given by employers who conducted the practical training showed that the students only managed to obtain a score between 3-4, which is under the satisfactory level. Among the elements of the problem are communication skills, personality, lack of discipline, the ability to implement directives, less creativity as well as enthusiasm. Employers also expressed that the students lack of confidence to carry out their work due to lack of information on the work they do (Laporan Unit Latihan Industri Kolej Komuniti Masjid Tanah 2009). The employer's response may be associated with students' low career self-efficacy. Low self-efficacy career appeared to cause difficulties for other forms of career assignments they want to select later (Betz \& Hackett, 1989).

1

The initial information obtained implies the need to implement the program in the form of a comprehensive career intervention that can trace the career development of community college students. According to the Career Development Theory (Super, 1957), students at the age of 18-24 years are at the exploratory stage of career development and the main activity that should be carried out by students is to explore and gather as many career information as they could. On the other hand, they must also be exposed to more career programs in order to get more information for them. The information obtained can be used in career planning and decision-making.

To help improve the ability of career planning, career self-efficacy and career maturity among community college students, a modular intervention was introduced. Modular career intervention methods have been proven effective by the previous researchers (Devarajoo, 2002; Tan, 2004; Abd Hanid, 2007; Syed, 2007; Miles, 2008; Thuria Moore, 2003; Bleir, 2006). The study proves that an involvement in a structured career program provides opportunities for low achievement students to build their self-potential (Hirschi \& Lage 2008; Tarigan 2011). In another study, it is also proven that developments occur not only in terms of career planning, career decision making and career knowledge but also involve in the other aspects of their self-development (Castellano,Stone, Stringfield, Farley, \& Wayman 2004; Hughes \& Karp. 2004)

Up to this day, no follow-up study was conducted in response to the career issues among the student community college. Even though studies related to career intervention is carried out in the country but it was more focused on high school students (Amla, 2002; Devarajo0, 2002; Sidek ,2002; Tan, 2004; Abd Hanid, 2007; Syed ,2010; Poh et al. 2010; Sani, 2011). No research has been carried out in college or university level in this country, while studies in other countries showed that the career intervention programs have a positive impact on career development, self-efficacy and career maturity of students (Brown, 2000; Richard, 2001; Gail \& Kelly, 2004; Scot \& Ciani's, 2008; Sara June, 2006; Daria, 2006; Medina, 2010).

There are gaps especially on researches that include career intervention modules among community college students. This study was conducted to fill in the gaps. This study examines the Career Exploration Module that has been given added value by including skills that are appropriate for students such as interview skills, resume preparations and how to write job applications. The main objective of this study is to look at the differences of career planning abilities, career self-efficacy and career maturity of students between two community colleges in the state of Malacca.

\section{Methodology}

A quasi-experimental design was used to evaluate using non-equivalent pre-test and post-test control group (Campbell dan Stanley 1963, Salkin 2000, Wiersma 1991). A quasi-experimental design was chosen because the sample was not randomly selected (Johnson \& Christensen, 2000). The sample was chosen using intact group method, which means that the entire class was chosen to participate in the study (Johnson Homer \& Solso, 1978), in our case, college classes (Hirschi \& La"ge, 2008; Shadish, Cook, \& Campbell, 2002; Wiersma, 2000). The experimental group participated in a workshop using a Career Exploration Module for 9 weeks (18 hours), while the control group had their learning process in classes according to their schedules. A sample of 122 study participants (56 women and 66 men) were selected using purposive sampling method. The sample consisted of students taking Certificate of Hotel and Catering courses, Automotive, Computer Systems and Support, and Landscape from two community colleges in the state of Malacca.

Data were collected using three sets of instruments: i) Career Planning Competencies Instruments adapted from Abd Hanis (2007), ii) Career Maturity Inventory-Revised (CM-R) 1995 by John O' Crites and Savuckas translated by Sani (2011) and, iii) Career Decision Making Self Efficacy Scale (CDMSE-SF) by Betz et al. (1996) translated by Sani (2011). A pilot study has been tested on 30 Semester Four students from Jasin College Community. Cronbach's values for these three instruments were $0.75,0.96$ and 0.94 for the KMK, CMR and CDMSE-SF. 


\section{The Findings}

\subsection{The mean score of the experimental group and a control group for career planning capabilities}

The mean score according to groups showed that there is a difference in mean between the experimental group, control group and pre-test(experiment, mean=2.79, s.p=.25864, control, mean=2.90 s.p .27357), post-test (eksperiment , mean=3.90 s.p=.40446, control, min=2.55, s.p=.28960). (Table 1)

Table 1: Mean score in the ability of career planning in pre and posttest based on groups

\begin{tabular}{lccccc}
\hline Groups & $\mathbf{N}$ & Mean of Plan Abilities Pra & Standard Deviation & Mean of Plan Abillities Post & Standard Aviation \\
\hline Experiment & 61 & 2.79 & .25864 & 3.90 & .40446 \\
Control & 61 & 2.90 & .27357 & 2.55 & .28960 \\
\hline
\end{tabular}

To ensure the difference of mean scores in the ability to plan career are at the significant level of $p<0.017$, MANOVA analysis was conducted. The results showed that the difference is significant at the value of $F=42,311, p=0.00, p<$ 0.017. This shows that the Career Exploration Module has effectively improve the ability for career planning in experimental group. (Table 2).

Table 2 Mean score differences on the ability of career planning between groups.

\begin{tabular}{|c|c|c|c|c|c|c|c|}
\hline \multirow{2}{*}{ Dependent Variable } & \multirow{2}{*}{ (I) Method } & \multirow{2}{*}{ ( J ) Method } & \multirow{2}{*}{ Mean Difference I - J } & \multirow{2}{*}{ Error } & \multirow{2}{*}{ Sig. } & \multicolumn{2}{|c|}{ Confidence Level 95\% } \\
\hline & & & & & & Lower Limit & Upper Limit \\
\hline Career & Module & Non module & 1.339 & .073 & .000 & 1.195 & 1.484 \\
\hline Ability Planning & Non module & module & -1.339 & .073 & .000 & -1.484 & -1.195 \\
\hline
\end{tabular}

\subsection{Career self-efficacy mean scores of the experimental and control group}

Career self-efficacy mean scores by group showed the difference in mean between the experimental group, control group, and pre-test. (experiment, mean $=3.97, \mathrm{~s} . \mathrm{p}=0.38$, control, meann=3.99, s.p=0.38), pre-test (experiment, mean=4.01, s.p=0.37, control , mean=3.56, s.p=0.35). ( Table 3)

Table 3. Mean score difference on the self-efficacy pre-test and post-test by group.

\begin{tabular}{|c|c|c|c|c|c|}
\hline Group & $\mathrm{N}$ & Mean Self Efficacy pra & Standard Aviation & Mean Self Efficacy post & Standard Aviation \\
\hline Experiment & 61 & 2.64 & .30777 & 3.74 & .53194 \\
\hline Control & 61 & 2.83 & .34709 & 2.53 & .39463 \\
\hline
\end{tabular}

To ensure self-efficacy career mean difference is significant at the level of $p<0.017$, MANOVA analysis was conducted. The results showed a significant difference which is the value of $F=176,020, p=0.000, p<0.017$. This means that the Career Exploration Module effectively enhance self-efficacy in career of experimental group. (Table 4)

Table 4. Mean difference of self-efficacy in career between the group.

\begin{tabular}{|c|c|c|c|c|c|c|c|}
\hline Dependent Variable & (I) Strategy & ( J ) Strategy & Mean Diff. I - J & Standard Aviation & Sig. & $\begin{array}{l}\text { Confidence } \\
\text { Lower Limit }\end{array}$ & $\begin{array}{l}\text { Level } 95 \% \\
\text { Upper Limit }\end{array}$ \\
\hline \multirow{2}{*}{ Self Efficacy } & Module & Non Module & 1.270 & 0.96 & .000 & 1.080 & 1.460 \\
\hline & Non Module & Module & -1.270 & 0.40 & .000 & -1.460 & -1.080 \\
\hline
\end{tabular}

\subsection{Career maturity mean scores of the experimental and the control group}

Career maturity mean scores by group showed the difference in mean between the experimental group and the control group, pretest (experiments, mean $=3.00, \mathrm{SP}=.19596$, control, mean $=3.16, \mathrm{SP}=.22320$ ), post test (experiment, mean $=3: 45, \mathrm{sp}=.19782$, control, mean $=3.27, \mathrm{SP}=0.18668) .($ Table 5$)$ 
Table 5. Mean score differences of career maturity in pre and post-test by group.

\begin{tabular}{|c|c|c|c|c|c|}
\hline Group & $\mathrm{N}$ & Mean Career Maturity pra & Standard Aviation & Mean Career Maturity post & Standard Aviation \\
\hline Experiment & 61 & 3.00 & .19596 & 3.45 & .19782 \\
\hline Control & 61 & 3.16 & 22320 & 3.27 & 18668 \\
\hline
\end{tabular}

To ensure that the mean differences of career maturity is at a significant level of $p<0.017$, MANOVA analysis was conducted. The findings show that the difference is significant, the value of $F=21,604, p=0.000, p<0.017$. This means that the module Traveler Career effectively improve career maturity experimental group. (Table 6)

Table 6. Mean difference between the group of career maturity

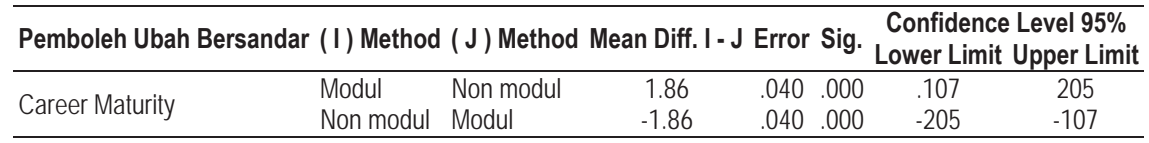

\section{Discussion and Summary}

The results of this study found that students' career planning abilities had improved after following a career intervention program using the Career Exploration Module. The findings of this study supported the previous studies that reported this intervention program module had successfully boosted the career planning ability of students. Several studies presented to support these findings are (Richard, 2001; Gail \& Kelly, 2004; Scot \& Ciani's, 2008; Syed, 2010; Miles,2008; Daria. 2006; Sara June, 2006; Abd Hanid, 2007; Andreass, 2007). The results of this study imply that students will be able to improve their ability to plan for their career if they are given a systematic exposure using a career module.

Meanwhile, this Career Exploration Module also effectively increases self-efficacy in career. These findings are consistent with previous studies that also found a career intervention program module which successfully increased students self-efficacy in careers (Sulivan \& Mahalik, 2000; Richard, 2001; Scot \& Ciani's, 2008; Medina, 2010; Medianta, 2011; Thuria Moore, 2003; Bleir, 2006; Sani, 2011). In addition, this Career Exploration Module is also capable in enhancing career maturity. Previous studies has been submitted to support the findings (Gail \& Kelly, 2004; Poh et al.,2010; Devaraajo0, 2002; Tan, 2004; Legum \& Hoare,2004; Andreas, 2007). This shows that career self-efficacy and career maturity can be increased if the students are given the opportunity to follow a career intervention program that uses the Career Exploration Module.

The results of this study gave two theoretical implications. First, Super Career Development Theory (1957 assumed individuals who are at an intermediate stage and trial (aged 18-24 years) have to explore career-related information. Exploration of information would trigger an interest, satisfaction and make people more confident and is able to make judgments based on the career information. This is parallel with the activities done by the students during the workshop using the Career Exploration Module, which were more focused on career information exploration activities.

This theory stated that career maturity and career planning abilities of the individual can be improved if the individual pays more attention and shows interest in the career development process. Individuals can heighten the ability to plan, interest and maturity of their career if exposed to an environment that can stimulate them towards it (Tarigan, 2011; Hirschi \& Lage, 2008; Medina, 2010). Activities throughout the workshop using this Career Exploration Module would encourage students to improve their ability to plan for their careers and make them more mature in their career direction.

The findings also showed that the level of career self-efficacy can be enhanced with the presence of encouragement, support, experience and interaction with the environment. This is consistent with the explanation by Bandura Social Cognitive Theory (1977), which presupposed self-efficacy can be improved through experience, learning, motivation and encouragement as well as individual's interaction with the environment. In this study, a conducive setting workshop environment has given students the opportunity to interact with other fellow participants. In addition, assistance, encouragement and incentives provided by the facilitators also contributed to the improvement of students' career self-efficacy.

The practical implications of this study proved that the career intervention program using the Career Exploration Module has contributed to enhancing the ability of career planning, career self-efficacy and student career maturity. 
Careers Exploration Module activities focused on the aspects of the work environment, career information exploration and preparation work and this also includes resume preparation, cover letter and job interview preparation. All these elements must be highlighted in future career programs. In conclusion, these findings imply that the use of the Career Exploration Module has proven to increase the ability of career planning, career self-efficacy and career maturity.

\section{References}

Abd Hanit bin Halit. 2007. Keberkesanan program kerjaya keatas perkembangan kerjaya peringkat penerokaan dalam kalangan pelajar sekolah menengah di Daerah Dungun Terengganu. Tesis. Dr. Fal. Universiti Putra Malaysia, Serdang.

Abdul Rahim Abd Rashid. 2006. Agenda perubahan pengurusan sumber manusia dan kerjaya.Kuala Lumpur: Utusan Publications \& Distributors Sdn Bhd.

Amla Salleh. 2002. Memindahkan ujian psikologi: Kaedah menterjemah dan mengubahsuai "Self Directed Search" (Holland) ke dalam bahasa melayu. Jurnal Pendidikan 16: 23-34.

Andreas Hirschi., Damian .L. 2008. Increasing The Career Choice Readiness Of Young Adolescents: An Evaluation Study. Education Vocational Guidance 8:95-110.

Bandura, A. 1977. Social Learning Theory. Englewood Cliffs, NJ: Prentice-Hall, Inc.

Bandura, A. 1997. Self efficacy: the exercise of control. New York: Freeman and Company.

Betz, N. E. \& Hackett, G. 1981. The relationship of career related self efficacy expectation to perceived career option in college women and men. Journal of Counseling Psychology, 28: 399-410.

Betz, N.E., \& Hackket, G. 1999. Manual of the occupational Self Efficacy Scale. Ohio State University \& Arizona State University.

Brown, M. T. 2000. Blueprint for the assessment of socio-structural influences in career choice and decision making. Journal of Career Assessment, 8, 371-378.

Bertha M. Medina. 2010. Career course impact on adolescents' levels of career decision self-efficacy, hope, and self-esteem. Doc. Of Philosophy: Northcentral University, Arizona.

Bleier, J.K. 2006. The impact of career counseling plus discover (internet version) on the academic achievement of high school sophomores at risk for dropping out of school.the Faculty of the Graduate School Doctor of Philosophy. University of MissouriColumbia.

Cambell, D.T. \& Stanley, J.C. 1963.Experimental and quasi-experimental designs for research. Chicago, Illlinois: Rand McNally. Programmes. Alexanderia, VA: American School Counselor Association Press.

Daria Williamson. 2006. The effect of career education mini-course on the career decision-making skills of high school students. Doc. Of Philosophy: University of Georgia.

Devarajoo Ponnan. 2002. Kesan modul motivasi ke atas sikap kematangan kerjaya di kalangan pelajar sekolah menengah di Selangor. Tesis Sarjana Universiti Putra Malaysia.

Serdang. Ettinger, J. 1998. Sharping tomorrow's workforce today. High school magazine,5,26-31.

Gail Ann Kelly Roaten. 2004. The effects of a career development intervention on the career decision making skills of high school student. Doc. Of Philosophy: Texas A \& M University.

Hairunnaja Najmuddin 2008. Membimbing remaja memilih pendidikan dan kerjaya, PTS. Kuala Lumpur.

Hirschi, A., \& La"ge, D. 2008. Increasing the career choice readiness of young adolescents: An evaluation study. International Journal for Educational and Vocational Guidance, 8, 95-110.

Hughes, K.L \& Karp,M.M. 2004. School-based careeer development: a synthesis of the literature. New York: IEE, teaching College,Columbia University.

Jean Miles. 2008. The impact of a career development programme on career maturity and academic motivation. Doc. Of Philosophy: Fort Hare University, London.

Johnson, B., \& Christensen, L. 2000. Educational research: Quantitative and qualitative. Boston: Allyn.and Bacon Company.

Johnson Homer, H., \& Solso, R. 1978. An introduction to experimental design in psychology: A case approach (2nd ed.). New York, NY: Harper \& Row.

Kementerian Pengajian Tinggi Malaysia. 2008. Laporan pengesanan graduan. Bahagian Pengurusan Kolej Komuniti.

Legum, H. L., Hoare, C. H. 2004. Impact of a Career Intervention on At- Risk Middle School Students' Career Maturity Levels, Academic Achievement, and Self-Esteem. Professional School Counselling, Vol. 8, Issue 2.

Miles, J. 2008. The Impact of a Career Development Programme on Career Maturity and academic Motivation. Degree of Master of Sicial Scienes.

Mizan Adiliah. 2005. Kajian Mobaliti Perkhidmatan Bimbingan dan Kaunseling Kolej Komuniti. Kementerian Pengajian Tinggi Malaysia.

Pallant, J. 2007. A Step by Step Guided to Data Analysis Using SPSS for Windows Version 12, Open University Press, Buckingham, Philadelphia.

Poh Li, Lau, Aqeel, Khan , Haslee Sharil Abdullah and Fong Peng Chew. 2010. The Effectiveness of Career Exploration Program for High SchoolStudents. University of Malaya Faculty of Education, Kuala Lumpur.

Richard G. Brake, M.A. 2001. The effects of discover career guidance software on career decision-making-self efficacy of adolescents in foster care. Doc. Of Philosophy. Our Lady of The Lake University, Texas.

Shadish, W. R., Cook, T. D., \& Campbell, D. T. (2002). Experimental and quasi-experimental design for generalized causal inference. Boston: Houghton Mifflin Company. 
Sara, J. Munger, 2006. The impact of a career exploration group. Doc.Of Philosophy: State University of New York College.

Savickas, M.L. 1990. The use of career choice measures in counseling practice. Testing in Counseling Practice. Hillsdale: HJ Erlbaum.

Scott, A.B., \& Ciani, K.D. 2008. Effect of an undergraduate career class on men's and women's career decision-making self-efficacy and vocational identity. Journal of

Sidek Mohd Noah. 2002. Reka bentuk penyelidikan : falsafah,teori dan praktis. Serdang: Penerbitan Universiti Putra Malaysia.

Syed Mohamad Syed Abdullah. 2005. Keberkesanan modul merancang kerjaya ke atas motivasi belajar, Kemahiran belajar dan kebolehan merancang kerjaya pelajar berpencapaian rendah. Tesis Dr. Falsafah. Universiti Kebangsaan Malaysia. Bangi.

Super D.E. 1957. The Psychology of career. New York: Harper \& Row Publisher. Career Information, Career Counselling \& Career Development. $7^{\text {th }}$, Ed. Boston: Allyn and Bacon.

Tan Wat Jin. 2004. Kesan pelaksanaan modul kerjaya terhadap kematangan kerjaya pelajar sekolah menengah. Tesis Sarjana Universiti Putra Malaysia, Serdang.

Thuria, M. 2003. The impact of career development classes on the identity development and career self efficacy of traditional aged college students. Dissertation of Doc. Of Philosophy: School of The Ohio State University.

Wiersma, W. (2000). Research methods in education. Boston: Allyn \& Bacon. 